\title{
Evaluation of the Situation of the People Received Service from Equine Facilities Before and During the Covid-19 Pandemic
}

\author{
Ayşe Kocabıyık ${ }^{1 *}$, Fatih Şahiner ${ }^{2}$, Demet Gökdere ${ }^{1}$, Elif Rabia Şanli², Musa Yavuz² \\ ${ }^{I}$ Department of Laboratory and Veterinary Health, Şarkikaraağaç Vocational School, Isparta University of Applied \\ Sciences, Isparta, Turkey \\ ${ }^{2}$ Isparta University of Applied Sciences, Faculty of Agriculture, Department of Animal Science, Isparta, Turkey \\ *Corresponding author. Email: aysekocabiyik@isparta.edu.tr
}

\begin{abstract}
The covid-19 pandemic influences human social life and their relation to animals. The equine sector is affected by covid-19 pandemic. The aim of this study was to evaluate the general situation of the people receiving service from equine facilities before and during the pandemic. The data were collected from questionnaires based on the pandemic awareness, the measures taken, the time spent with horses and the socio-economic effects of these factors. Considering our survey results, the number of people who spent 0,5 hours at the facility increased by an average of $31 \%$ (April) and 38\% (May) during the pandemic period compared to the pre-pandemic month (March), and during the transition to controlled social life (June-July), it was increased 19-11\%, respectively. This situation has been attributed to the facilities which allow people to maintain social distance and psychological effects of horses on humans. There are a negative relationship between the facility density and the time spent at the facilities. People were aware that there will be no contamination from horses. Pandemic sanitary practices were used at the facility for humans. However, they did not sanitized horses or their equipment. Overall facility workers and the questioners did not get the Covid-19.
\end{abstract}

Keywords: Equine, Covid-19 pandemic, Services, Survey

\section{INTRODUCTION}

Historically horse breeding is one of the important characteristics of culture in Turkey. Horses are not only animals or vehicles but also they have been seen as helpmates and companions to humans [1]. According to the FAO 2017 data, the countries with the highest horse presence in the world are the USA (10 511 000), Mexico (6 380 000), and China (5 507 000). Turkey ranks 52 in the world with approximately 120 thousand horses [2]. According to the Turkish Statistical Institute (TurkStat) data, there were 102467 horses in Turkey in 2019. It is recorded that Isparta ranked 52 in Turkey with 538 horses [3].

The place of horses in human life has changed over time. In the past, horses are used in the army and agriculture afterwards, they have entered our lives in the fields of sports, entertainment and health, and new sectors are established. Equine and horse breeding businesses are becoming widespread in the world and our country [4]. With the 250 thousand inhabitants, Isparta province is developing in terms of equestrian sports and, especially horseback riding is becoming increasingly popular. In four distinct horse farms, they provide horseback safari, horse riding, rider training and horse boarding services.

The epidemic, which emerged in Wuhan, Hubei province of China in December 2019 and called Covid-19 by the World Health Organization, has affected the whole world, almost all countries are tested, treated, quarantined, restricted gatherings to slow down the transmission of the disease [5].

In Turkey, the first Covid-19 case was detected on March 10, 2020, and the first death took place on March 15, 2020. It has been reported that by September 12, 2020, 6.999 people died and 1.241 people are still under intensive care. The total number of Covid-19 patients is 289.635 , while the number of recovered patients is 257.731 [6]. Social gathering places (restaurants, coffee house, shopping centers 
etc.) were banned [7]. For the people aged 65 and over and children aged 18 and under were not permitted to leave their houses unless they are obligated to go for hospital or government office [8]. The Covid-19 pandemic caused necessary changes in all areas of life and also it affected the equine industry. In this regard, the directives of staying home, social isolation and controlled social life have caused changes in the horse businesses for owners and riders. Infections always pose a risk in horse riding that requires constant movement [9]. It has been reported that situations such as not applying bio-security rules and uncontrolled mobility in the enterprise cause great negativity in the control of the spread of diseases in equine farms with high visitor mobility [10]. As in all livestock businesses, it is necessary to control movement in equine businesses [11].

In this study, it was aimed to evaluate the general situation of the equine establishments in Isparta, Turkey and the people receiving service from these facilities before and during the pandemic. The study was based on the pandemic awareness of the people serving and receiving the service, the measures were taken, the time spent with horses and the socioeconomic effects of these factors. The research data were determined by a questionnaire consisting of closed-ended (yes-no-answer) selective and openended questions with people serving and receiving services from different equestrian facilities in Isparta, Turkey.

\section{MATERIALS AND METHODS}

With the questionnaire, the general conditions of the equestrian businesses in Isparta, Turkey and the people receiving service from these facilities during the pandemic process were evaluated. For this research, four facility owners and 51 people receiving service from this facility were asked the questions. The survey questions were intended to determine the facility's bio-security practices before and after the pandemic, the change in the facility intensity, the number of people receiving service and the social measures taken (Table 1.).

\section{RESULTS AND DISCUSSION}

For this research, 51 service users and 4 facility owners have participated. Men and women participant numbers were $31(60.78 \%)$ and 20 (39.22\%), respectively. Regarding the age of the participants, 11 people $(21.56 \%)$ were under 20 years old while 40 people $(78.43 \%)$ were over 20 years old. When the educational status was evaluated, 7 (13.73\%) primary school, 11 (21.57\%) high school and 33 (64.71\%) bachelor graduates were responded the survey questions.
There were a total of 41 horses in 4 facilities in Isparta, Turkey. While 13 of these horses receive boarding service, 28 of them belong to the clubs and were used for riding, training and field trips. The survey was conducted on 51 people with 9 of them licensed for horseback riding. They also receive horse riding training, hostel service and restaurant services from the facility. While 36 of these people were at the basic riding training level and 15 of them were freerider.

Table 1. Survey questions.

\begin{tabular}{|c|c|}
\hline 1 & What are your gender and educational background? \\
\hline 2 & How long have you been riding? \\
\hline 3 & What are the services provided at the facilities? \\
\hline 4 & Do you own a horse? \\
\hline 5 & What is your riding level? \\
\hline 6 & Do you have a riding license? \\
\hline 7 & $\begin{array}{l}\text { How did the time you ride a horse change during the } \\
\text { pandemic? }\end{array}$ \\
\hline 8 & Have people caught Covid-19 around you? \\
\hline 9 & Did anyone Covid-19 positive in the facility? \\
\hline 10 & $\begin{array}{l}\text { What precautions are you taking to protect yourself } \\
\text { from Covid-19? }\end{array}$ \\
\hline 11 & $\begin{array}{l}\text { Which precautions taken at the facility during the } \\
\text { pandemic have drawn your attention? }\end{array}$ \\
\hline 12 & Have any special measures been taken for horses? \\
\hline 13 & $\begin{array}{l}\text { Do you think Covid-19 can be transmitted from horses } \\
\text { to humans? }\end{array}$ \\
\hline 14 & $\begin{array}{l}\text { Did you worry about the possibility of contagion in } \\
\text { your association with horses during the pandemic? }\end{array}$ \\
\hline 15 & $\begin{array}{l}\text { Has the pandemic process affected your time with } \\
\text { horses? }\end{array}$ \\
\hline 16 & $\begin{array}{l}\text { Has there been any change in the time you spend at the } \\
\text { facility since March? }\end{array}$ \\
\hline 17 & How many hours per day do you spend at the facility? \\
\hline 18 & How long do you ride a horse in a day? \\
\hline
\end{tabular}

Considering our survey results, compared to the pre-pandemic (March), the number of people who spent 0,5 hours at the facility increased by an average of $31-38 \%$ during the pandemic period (April-May). It was also increased around $19-11 \%$ during the transition to controlled social life period June-July. 
While the number of those who spent 1 and 2 hours decreased, the number of those who spent 3 hours increased (Figure 1). It was determined that people who spent 3 hours were owners of horses and preferred land rides.

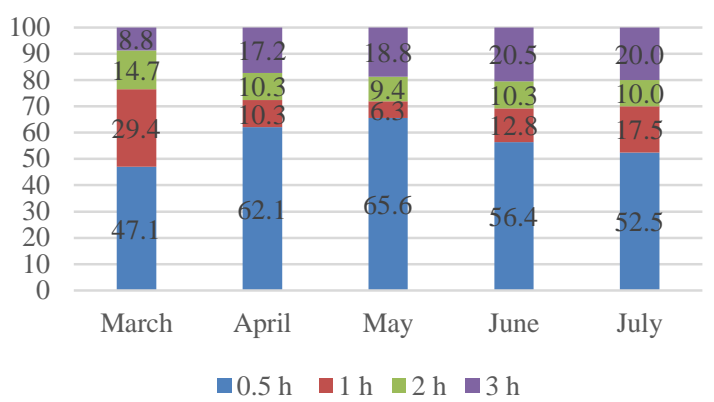

Figure 1 Riding time spend by months in the farm

On the other hand, $25.49 \%$ of the participants reduced the use of masks and usage of the disinfectants because they were outside. Besides, it has been determined that there was a negative correlation between the facility density and the time spent at the facility. According to survey, $86.27 \%$ of the participants said that there is no contamination of Covid 19 from horses to humans. While $49.01 \%$ of them had no idea about the implementation of pandemic specific practices for horses and barns in farms; however, $29.4 \%$ of them stated that they noticed that measures were taken in the farms. Business owners reported that during the pandemic, the work intensity and the time spent by riders with horses increased except the curfew periods. In the farms, there were warning signs and the seating areas were appropriate for the social distance. Also, in the facilities, contact between horses and people was reduced and the employees were more careful about hygiene. For example, hand disinfectants were used before and after boarding.

Most of the people $(80.39 \%)$ stated that they were paying attention to wearing masks and maintaining social distance (Figure 2).

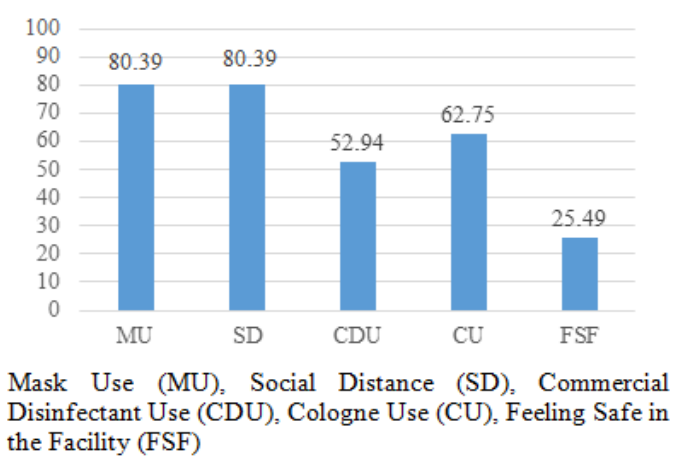

Figure 2 Individual protection measures taken in the farm
Moreover, $50.98 \%$ of them stated that they prefer to stay at home. Since all participants were careful about hand disinfection especially the cologne $(62.75 \%)$ which is traditional for hand disinfection in Turkey.

\section{CONCLUSION}

Considering our survey results, compared to the pre-pandemic (March), the number of people who spent 0.5 hours at the facility increased by an average of $31-38 \%$ during the pandemic period (April-May), respectively. It was also increased around $19-11 \%$ during the transition to controlled social life period (June-July). Because, open air and horses are good for human psychology and it is easier to maintain social distance in the farm. Time spent were changed. Especially short (30 $\mathrm{min})$ and long (3 hours) visits were increased; however, 1 - 2 hours visits were decreased. This may be due to the fact that people want to make short visits because of the risk of infection and it was easier for horse owners to maintain social distance by land rides. As a result of our study, it was determined that personal precautions were applied at a higher rate.

Positive results of national and local exhortations have been observed. Since it was easy to access traditional hand disinfection, people were choice the cologne as hand disinfection. To control and prevent the diseases, it is important to reduce the mobility and regulate the feed, equipment and movement of vehicles and personnel. It has been determined that these important measures were taken into consideration in the facilities. Facilities provided a hygienic environment to make the visitors feel better which led an increase in the time spent and psychological relaxation. It is known that psychological factors play an important role in human health. The data obtained from our study showed that the association between people and horses contributed to human health by reducing the stress during the pandemic which was a psychologically difficult period.

\section{ACKNOWLEDGMENTS}

We would like to thank the managers and employees of the Safkanlar, Isparta, Atabey and Doru Equestrian Sports Clubs, who made our work possible.

\section{REFERENCES}

[1] F. Şahiner, A. Kocabıyık, M. Yavuz, Body condition score in farm horses, Isparta example. International Marmara Sciences Congress (Spring) 756 (2020) 19-20. 
[2] Anonymus, The number of horses in the world by country, 2020. https://www.drdatastats.com/4ulkelere-gore-dunya-at-varligi/

[3] TurkStat, Livestock Statistics: 2004-2019', 2020: www.tuik.gov.tr.

[4] İ.G. Yildırım, H. Erden, Investigation of the general body structure of horses by morphometric methods, (in Turkish), Adnan Menderes Universty Healty Sciences Institute, Department of Anatomy Master's Thesis, 2007.

[5] I. Chakraborty, P. Maity, COVID-19 outbreak: Migration, effects on society, global environment and prevention, Sci.Total Environ. 728 (2020) 138882.

[6] Anonymus, Covid-19 pandemic in Turkey, 2020. https://tr.wikipedia.org/wiki/türkiye\%27de_COVI D-19_pandemisi

[7] Anonymus, Offical gazette on parks, picnic areas scope of combating the COVID-19, 2020. https://www.icisleri.gov.tr/koronavirus-salgini- ile-mucadele-kapsaminda-park-mesire-piknikyerleri-ile-ilgili-ek-genelge

[8] Anonymus, Offical gazette on Curfew Restriction 2020. https://www.icisleri.gov.tr/81-il-valiligine18-yas-alti-ile-65-yas-ve-uzeri-kisilerin-sokagacikma-kisitlamasi-genelgesi.

[9] J.S. Weese, Infection control and biosecurity in equine disease control, Equine Vet J. 46(6) (2014) 654-60.

[10] S.M. Rosanowski, N. Cogger, C.W. Rogers, An investigation of the movement patterns and biosecurity practices on Thoroughbred and standardbred stud farms in New Zealand, Prev Vet Med. 108(2-3) (2013) 178-187.

[11] K. Schemann, M.P. Ward, F.I. Lewis, S.M. Firestone, N.K. Dhand, J.A.L.M.L. Toribio, M.R. Taylor, Untangling the complex interrelationships between horse managers' perceptions of effectiveness of biosecurity practices using Bayesian graphical modelling. Prevent. Vet. Med. 110 ((2013) 37-44. 